\title{
Effect of Nano-sized Gypsum on Germination, Seedling Indices and Seedling Vigour Indices of Wheat (Triticum aestivum)
}

\author{
Anupama Rawat*, Rajeew Kumar, Vijay Pal Singh and Bandana Bhatt \\ Department of Agronomy, College of Agriculture, G. B. Pant, University of Agriculture and \\ Technology, Pantnagar, U. S. Nagar (263145), Uttarakhand, India \\ *Corresponding author
}

\begin{tabular}{|c|c|}
\hline & A B S T R A C T \\
\hline $\begin{array}{l}\text { Nano-particles, } \\
\text { Nanotechnology, } \\
\text { Root, Shoot, } \\
\text { Wheat, Vigour }\end{array}$ & \multirow{3}{*}{$\begin{array}{l}\text { Lab experiment was conducted in the department of agronomy in the year } 2016 \text { to } \\
\text { study the effect of nano-sized gypsum on germination and seedling growth of wheat } \\
\text { (Triticum aestivum). The experiment consisted of four treatments which were laid out } \\
\text { in completely randomized design with the variety DPW 621-50. Germination } \\
\text { percentage and seedling growth indices varied significantly with treatments. Seeds } \\
\text { treated with nano-sized gypsum @ } 100 \text { ppm obtained maximum germination } \\
\text { percentage and root length and were found at par with nano-sized gypsum @ } 100 \text { ppm } \\
\text { and significantly higher over other treatments. Maximum shoot length and seeling } \\
\text { length was obtained with nano-sized gypsum @ } 100 \mathrm{ppm} \text { which was significantly } \\
\text { higher over rest of the treatments. On the basis of this study it can be concluded that } \\
\text { nano-sized gypsum has great potential in improving germination, emergence and } \\
\text { seedling vigour. Treating seeds with nano-sized gypsum @ } 100 \text { ppm enhances seed } \\
\text { germination, seedling indices and seedling vigour index. }\end{array}$} \\
\hline Article Info & \\
\hline $\begin{array}{l}\text { Acceptea: } \\
\text { 04 September } 2020 \\
\text { Available Online: } \\
10 \text { October } 2020\end{array}$ & \\
\hline
\end{tabular}

\section{Introduction}

Wheat is widely grown for its seeds, a cereal grain which is the most staple crop worldwide. It holds great significance in food security globally. In India, wheat stands second as the most important crop after rice with the area of 30 million ha and production of 93 million tons (Directorate of Economics and Statistics, Government of India, 2014). As the food requirement is increasing with increase in population, the food grain production needs to be enhanced accordingly. With the present scenario of deteriorated soil health and increased cost of inputs, the productions need to be increased sustainably without depleting soil health. Uniform and timely seed germination is one of the prior steps that ensures good and uniform plant stand which ultimately enhances yield. Seeds are treated prior to sowing for controlling pathogens and to enhance plant growth and yield. Soaking of seeds and treating those breaks down plant's natural defences and leads to faster germination.. Nano-particles are atomic and molecular aggregates of size in nano-scale range of 1-100nm (Rai and Ingle, 2012). Nano-particles of gold, silver, zinc, 
zinc oxide, copper, aluminium, silica cesium oxide, titanium dioxide and magnetized iron have found their application in agriculture (Zhang and Webster, 2009). Nano-particles generally have higher intercellular uptake than microsized particles and due to their small size and rapid mobility are available to wide range of biological target. Many researchers have found role of nano-particles in enhancing seed germination and seedling growth. Application of nano-particles has been proved to be effective in enhancing seed germination and seedling growth (Pandey et al., 2010). Engineered carbon nanotubes boost seed germination, growth and development of plants (Lahiana et al., 2013). Effect of mixtures of nano- $\mathrm{TiO}_{2}$ and nano$\mathrm{SiO}_{2}$ on soybean seeds resulted in increased enzymatic activity of nitrate reductase in soybean resulting in enhanced germination and growth (Lu et al., 2002). Nano-particles facilitate absorption of water and nutrients by the roots and enhance antioxidant enzyme activity such as catalase and superoxide dismutase. Hence, nano-particles can improve plant's tolerance against different stresses (Harrison, 1996). Engineered nano-particles can enter into the plant cells and can also transport DNA and chemicals into plant cells (Torney et al., 2007).

\section{Materials and Methods}

A lab experiment was conducted in the department of Agronomy, college of Agriculture, G. B. P. U. A. \& T. Pantnagar in the year 2016 in the month of November. The experiment consisted of four treatments viz. T1: Control (seeds were soaked in tap water), T2: Normal Gypsum @ 100 ppm, T3: Nanosized gypsum: @ 50 ppm, and T4: nano-sized gypsum @ 100 ppm. The treatments were laid out in completely randomized design with three replications. 50 seeds were arranges in circular pattern per petri plate. The solutions in which seeds were to be soaked were prepared by dissolving gypsum and nanosized gypsum in different concentrations in distilled water. The mixture was stirred using mechanical stirrer followed by dispersion using bath sonicator for 30 minutes. A stock solution of $1000 \mathrm{ppm}$ was prepared using $1000 \mathrm{mg}$ nano-sized gypsum per litre of distilled water. Using this stock solution of different concentration were prepared using formula $\mathrm{C}_{1} \mathrm{~V}_{1}=\mathrm{C}_{2} \mathrm{~V}_{2}$. After this, 50 healthy seeds were soaked in $100 \mathrm{ml}$ solution of different concentrations as per the treatment for four hours followed by air drying. The seeds were then arranged in perti plates containing filter paper wetted with water. The petri dishes were kept in an incubator set at $21 \pm 1{ }^{\circ} \mathrm{C}$ for 8 days. The petri plates were inspected daily for any fungal attack. Water was sprinkled over the seeds as and when required.

Observation for germination was recorded from the second day onwards. Seeds are considered germinated when both radical and plumule emerge. Percent germination was calculated using the following formula

Germination $\%=\frac{\text { number of normal seedlings }}{\text { total mumber of seeds sown }} \times 100$

Seedling growth parameters were recorded 8 days after incubation. Ten random seedlings were selected for taking observations. Root and shoot length were measured using scale and then placed in hot air oven at $72^{\circ} \mathrm{C}$ till constant weight is attained and then weighed for root and shoot dry weight.

Seedling vigour index-I (SVI-I) and Seedling vigour index-II (SVI-II) were computed using formula suggested by Abdul Baki and Anderson (1973).

SVI-I $=$ Germination percentage $\times$ seedling length $(\mathrm{cm} /$ seedling $)$ 
SVI-II $=$ Germination percentage $\times$ seedling dry weight ( $g /$ seedling)

\section{Results and Discussion}

The results of the experiment obtained are discussed under the following heads (Fig. 13 ; Table 1 and 2).

\section{Germination percentage}

A seed was considered germinated when both the plumule and radicle were visible. Seed germination percentage was recorded after second day of the experiment. Germination percentage varied significantly with treatments. Maximum germination percentage was obtained in seeds which were treated with nano-sized gypsum @ 100 ppm and was found at par with nano-sized gypsum @ 50 ppm and significantly higher over other treatments.

\section{Seedling indices}

Maximum root length was found with nanosized gypsum @ 100 ppm which was at par with @ 50 ppm and significantly higher over rest of the treatments. Seeds treated with nano-sized gypsum @ 100 ppm resulted in maximum shoot length and seedling length which were significantly higher over the rest of the treatments. Root dry weight, shoot dry weight and seedling dry weight varied significantly with different treatments. Maximum root dry weight, shoot dry weight and seedling dry weight were obtained with nano-sized gypsum @ 100 ppm which was significantly higher over rest of the treatments. It is evident from the results that nano-sized gypsum has the capacity in improving seedling growth indices viz. root length, shoot length, seedling length, root dry weight, shoot dry weight and seedling dry weight.

\section{Seedling vigour indices}

Seedling vigour indices of 8 days old seedlings were found significant due to treatments. Significantly higher seedling vigour index I and seedling vigour index II were obtained with nano-sized gypsum @ 100 ppm. Among bulk gypsum and nano-sized gypsum, nano-sized gypsum @ 50 ppm gave significantly higher seedling vigour indices compared to bulk gypsum @ 100 ppm.

The above results might be due to seed priming with nano-sized particles which easily penetrated the seed coat and enhanced water uptake, thus improving germination and emergence rate. Better emergence and seedling growth resulted in high seedling vigour indices.

Table.1 Germination percentage as influenced by different treatments

\begin{tabular}{|c|c|}
\hline Treatment & Germination \% \\
\hline Control & 92.6 \\
\hline Gypsum @ 100 ppm & 94.0 \\
\hline NG @ 50 ppm & 98.6 \\
\hline NG @ 100 ppm & 99.3 \\
\hline S.Em \pm & 0.8 \\
\hline C. D $($ at 5 \%) & 2.7 \\
\hline C. $\mathbf{V}(\mathbf{\%})$ & 1.4 \\
\hline
\end{tabular}


Table.2 Seedling growth indices of wheat as affected by seed soaking in gypsum and nano-sized gypsum solutions at different concentrations

\begin{tabular}{|c|c|c|c|c|c|c|c|c|}
\hline Treatment & $\begin{array}{c}\text { Root length } \\
\text { (cm/seedling) }\end{array}$ & $\begin{array}{c}\text { Shoot length } \\
\text { (cm/seedling) }\end{array}$ & $\begin{array}{c}\text { Seedling } \\
\text { length } \\
\text { (cm/seedling) }\end{array}$ & $\begin{array}{c}\text { Root dry } \\
\text { weight } \\
\text { (mg/seedling) }\end{array}$ & $\begin{array}{c}\text { Shoot dry } \\
\text { weight } \\
\text { (mg/seedling) }\end{array}$ & $\begin{array}{c}\text { Seedling dry } \\
\text { weight } \\
\text { (mg/seedling) }\end{array}$ & $\begin{array}{c}\text { SVI I } \\
\text { SVI II }\end{array}$ \\
\hline Control & 4.8 & 3.3 & 8.1 & 4.3 & 4.0 & 8.3 & 754.4 & 772.2 \\
\hline Gypsum @ 100 ppm & 8.9 & 5.1 & 14.0 & 5.7 & 4.2 & $1,338.2$ & 921.3 \\
\hline NG @ 50 ppm & 11.9 & 6.1 & 18.1 & 6.3 & 4.3 & 10.6 & $1,788.6$ & 1049.1 \\
\hline NG @ 100 ppm & 12.4 & 7.2 & 19.6 & 6.8 & 5.3 & 12.2 & $1,956.1$ & 1211.7 \\
\hline S.Em & 0.2 & 0.1 & 0.2 & 0.1 & 0.1 & 0.4 & 24.3 & 12.9 \\
\hline C. D (at 5 \%) & 0.7 & 0.3 & 0.7 & 0.3 & 0.3 & 0.1 & 80.5 & 42.7 \\
\hline C. V (\%) & 3.9 & 3.3 & 2.7 & 2.6 & 3.3 & 0.2 & 2.8 & 2.3 \\
\hline
\end{tabular}

Fig.1 Effect of different treatments on length of root and shoot of wheat seedling

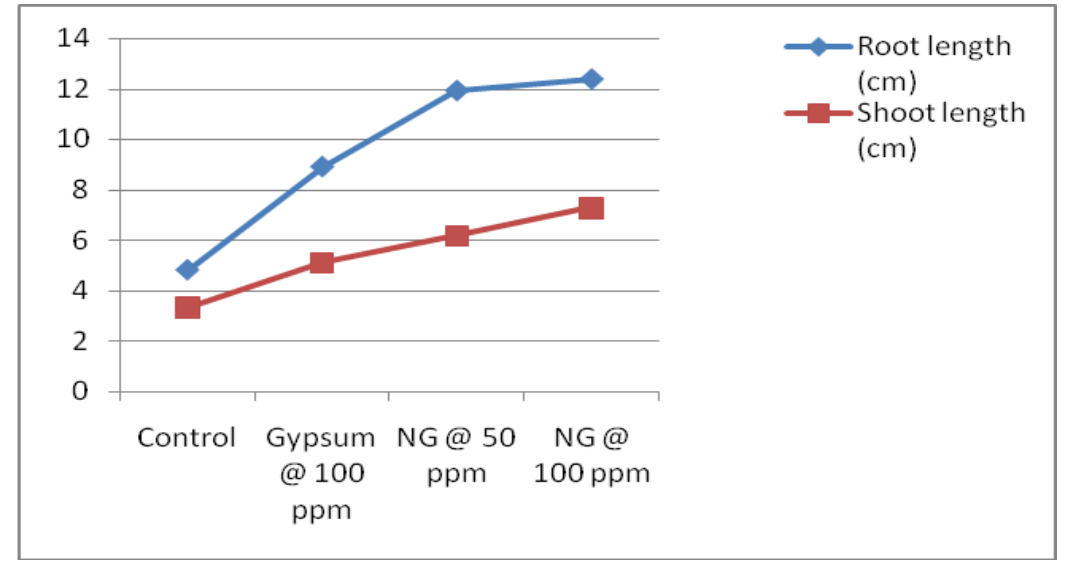


Fig.2 Effect of different treatments on dry weight of root and shoot of wheat seedling

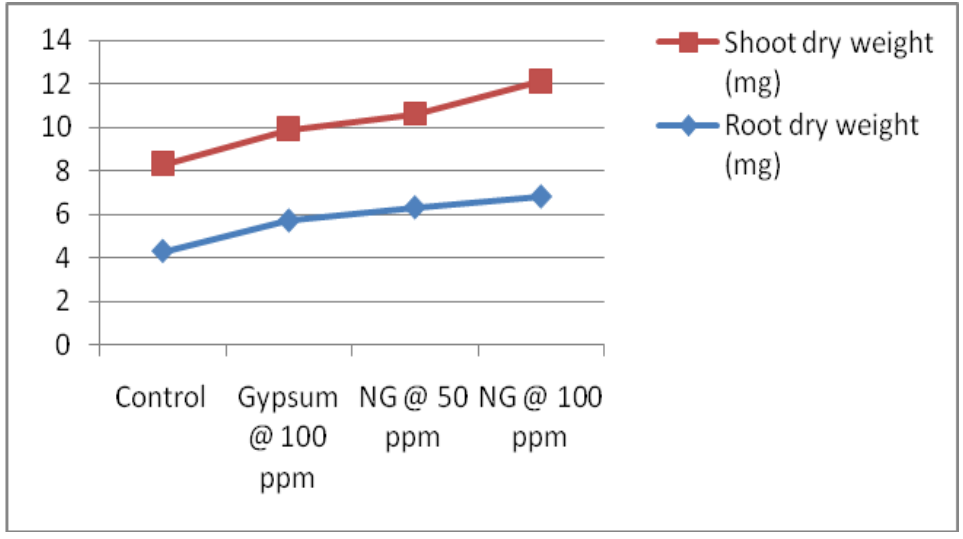

Fig.3 Effect of nano-sized gypsum on seedling growth of wheat

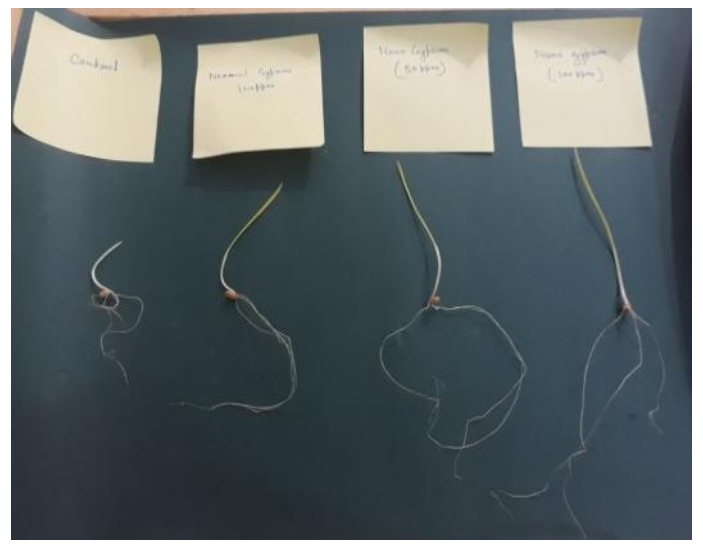

\section{Germination Percentage}

The increased germination percentage by soaking of seeds in nano-sized gypsum solution might be due to loosening of the seed coat. Smaller size of nano-sized gypsum and their high surface energy helped them in entering the seed coat and thus loosened it, which further facilitated the emergence of radicle and plumule. Moreover, with pore enlargement of cell membrane, they enter the cell more easily than the bulk gypsum and improved germination by increasing uptake of water. Feizi et al., (2011) also reported that in wheat, seed germination was promoted by application of nano- $\mathrm{TiO}_{2}$ in suitable concentration compared to bulk $\mathrm{TiO}_{2}$ and this may be possibly due to easy penetration of nano-anatase through seed coat which might have activated the embryo (Savithrama et al., 2012).

\section{Seedling indices}

The improvement in these parameters might be due to easy entry of nano-sized gypsum $\left(\mathrm{CaSO}_{4} \cdot 2 \mathrm{H}_{2} \mathrm{O}\right)$ particles into the seed, which might supply calcium and sulphur and helped to increase calcium and sulphur content in seed. Calcium is known to enhance root growth. Entry of nano-sized gypsum might have enhanced water uptake due to increase in the membrane pore size during the passage of nano-sized gypsum particles into the seed. High calcium content and enhanced water uptake might have enhanced cell elongation 
and cell division improving root and shoot growth. Prasad et al., (2012) also reported increase in root length, shoot length and vigour index with application of nanoscale $\mathrm{ZnO}$ in peanut.

\section{References}

Abdul-Baki, A., and Anderson, J. D. (1973). Vigor analysis in soybean seed by multiple criteria. Crop Science. 13: 630-633.

Directorate of Economics and Statistics. 2014. Government of India.

Feizi, H., Moghaddam, P. R., Shahtahmassebi, N. and Fotovat, A. 2012. Impact of bulk and nanosized titanium dioxide ( $\mathrm{TiO} 2)$ on wheat seed germination and seedling growth. Biological trace element research. 146(1): 101-106.

Harrison, C. C. 1996. Evidence for intramineral macromolecules containing protein from plant silicas. Phytochem. J. 41:37-42.

Lahiana, M. H., Dervishi, E., Chen, J., Nima, Z., Gaume, A., Biris, A. S. and Khodakovskaya, M. V. 2013. Impact of carbon nanotube exposure to seeds of valuable crops. ACS Appl Mater Interfaces. 5: 7965-7973.

Lu, C. M., Zhang, C. Y., Wen, J. Q., Wu, G. R. and Tao, M. X. 2002. Research on the effect of nanometer materials on germination and growth enhancement of Glycine max and its mechanism.
Soybean Science. 21: 68-72.

Pandey, A. C., Shjarda, S. S. and Yadav, R. S. 2010. Application of $\mathrm{ZnO}$ nano particles in influencing the growth rate of Cicer arientinum. J. Exp. Nanosci. 5(6): 448-497.

Prasad, T. N. V. K. V., Sudhakar, P., Sreenivasulu, Y., Latha, P. and Munaswamy, V. 2012. Effect of nanoscale zinc oxide particles on the germination, growth and yield of peanut. Journal of Plant Nutrition. 35: 905-927.

Rai, M. and Ingle, A. 2012. Role of nanotechnology in agriculture with special reference to management of insect pests. App Microbiol Biotechnol. 94(2): 287-293.

Savithramma, N., Ankanna, S. and Bhumi, G. 2012. Effect of nanoparticles on seed germination and seedling growth of Boswellia ovalifoliolata- an endemic and endangered medicinal tree taxon. Nano Vision. 2(3): 61-68.

Troney, F., Trewyn, B. G., Lin, V.S.Y. and Wang, K. 2007. Mesoporous silica nanoparticles deliver DNA and chemicals into plants. Nature Nanotechnol 2: 295-300.

Zhang, L. and Webster, T. J. 2008. Nanotechnology and nanomaterials: promises for improves tissue regeneration. Nano Today. 4(1): 6680 .

\section{How to cite this article:}

Anupama Rawat, Rajeew Kumar, Vijay Pal Singh and Bandana Bhatt. 2020. Effect of Nanosized Gypsum on Germination, Seedling Indices and Seedling Vigour Indices of Wheat (Triticum aestivum). Int.J.Curr.Microbiol.App.Sci. 9(10): 48-53.

doi: https://doi.org/10.20546/ijcmas.2020.910.007 